\title{
Why Has Leadership in the Asia-Pacific Proved So Elusive?
}

\author{
Mark Beeson ${ }^{1}$
}

Received: 26 August 2017/Accepted: 7 September 2017/Published online: 12 September 2017

(C) Fudan University and Springer Nature Singapore Pte Ltd. 2017

\begin{abstract}
Of the many things that distinguish what we now think of as the 'AsiaPacific', one of the most striking is the absence of effective regional leadership. The fact that there are a number of 'great powers' with potentially competing claims to leadership is one of the principal causes of overall leadership failure. The recent election of Donald Trump looks likely - whether by accident or design - to transform America's traditional relationship with East Asia and its role in the AsiaPacific, with potentially profound long-term consequences. This paper examines the possible implications of both the rise of China and the advent of the Trump era for regional development in general and leadership in particular. I suggest that the combination of China's reemergence and Trump's more instrumental attitude to international relations presents China with a possibly unique opportunity to reassert itself at the centre of regional, if not world affairs. Whether it has the capacity or the unequivocal desire to do so, however, is another question.
\end{abstract}

Keywords Leadership - Regionalism - Rise of China - Donald Trump · East Asia

\section{Introduction}

Of the many things that distinguish what we now think of as the 'Asia-Pacific', one of the most striking is the absence of effective regional leadership (Beeson 2016). Given that this geographical area contains some of the most powerful and important states in the world, this is rather surprising. Intuitively we might expect that a region that includes the United States, China and Japan ought to be well placed to offer

Mark Beeson

mark.beeson@uwa.edu.au

1 University of Western Australia, Perth, Australia 
effective and decisive leadership to other, less powerful states, given the economic and strategic resources they have at their disposal. And yet, the fact that there are a number of 'great powers' with potentially competing claims to leadership is one of the principal causes of overall leadership failure: in the absence of some sort of accommodation between the major states of the region, effective leadership, either individual of collective is very difficult if not impossible (White 2012).

Adding to 'the region's' problems is the fact that the very definition of the area under consideration is contested, and subject to competing 'visions', initiatives and depictions. Is the 'Asia-Pacific' really the most effective or 'natural' basis for regional cooperation and/or leadership in the first place? Would a narrower definition of the region such as East Asia or even the newly fashionable 'IndoPacific' actually be a more effective basis for cooperation, influence or even coercion? For the reality is that all of these regional arenas have been characterized by power projection, strategic tensions and even outright conflict at times. This historical baggage helps to account for the lingering animosities and absence of trust that makes any form of cooperation and coordination difficult, no matter how the region in question is defined (Emmott 2008).

Nevertheless, there have been moments when regional influence and orderbuilding have occurred, and we may be seeing something of a renaissance in more narrowly conceived forms of regional leadership remerging at the present juncture. The so-called rise-or more accurately, the reemergence - of China as a major power has the potential to provide leadership in the East Asian region in a way that it did for hundreds, if not thousands of years (Zhang and Buzan 2012). For this to happen, however, the role and status of the United States - and to a lesser extent, Japan-will have to be clarified and possibly redefined. This is what makes the recent election of Donald Trump so significant: the Trump administration looks likely — whether by accident or design - to transform America's traditional relationship with East Asia and its role in the Asia-Pacific, with potentially profound long-term consequences.

This paper examines the possible implications of both the rise of China and the advent of the Trump era for regional development in general and leadership in particular. It does this by placing the discussion in historical context and by exploring the nature of Chinese and American leadership at different periods. I shall suggest that the combination of China's reemergence and Trump's more instrumental attitude to international relations presents China with a possibly unique opportunity to reassert itself at the centre of regional, if not world affairs. Whether it has the capacity or the unequivocal desire to do so, however, is another question.

\section{Putting Leadership in Historical and Geographical Context}

At the outset it is important to recognize just how uncertain and contested the definition of the region in question actually is. For most of human history it literally made no sense to describe the region we now think of as 'East Asia' in that way. The simple reality was that there was no 'other' against which to distinguish East 
Asia. What connections there were with the rest of the world were tenuous, and the well known sense of superiority on the part of China's dynastic leaders encouraged a complacent insularity that left them entirely unprepared to meet the challenge of European imperialism. Before the economic and strategic expansion of the European powers brought about the downfall in China's own imperial system, however, China had exercised a distinctive and enduring from of leadership in its own neighborhood (Fairbank et al. 1965).

A number of comparative points are worth noting about the Tributary system in particular. First, China's dominance of its region not only lasted for hundreds, if not thousands of years, but it assumed a particular and distinctive form. On the one hand, it was relatively indirect and undemanding. Certainly there were important and enduring cultural influences, such as the export of Confucianism in particular (Rozman 1991), but the Chinese emperors demanded relatively little from their notional subordinates, other than the acknowledgement of China's superiority in return. In this regard, as Kang (2003) has astutely noted, China's style of imperial rule stands in stark contrast to modern forms of domination: while China's Tribute system was notionally hierarchical, in reality its dominance was generally not enforced and there was a good deal of equality in practice. The contemporary Westphalian order of notionally similar sovereign states, by contrast, may be predicated on the idea of equality, but in reality it has been anything but (Hobson and Sharman 2005). The contemporary international system is distinguished by high levels of political, economic and strategic inequality that give rise to a hierarchical state system in which some members are, to paraphrase George Orwell, decidedly more equal than others.

The other striking features of the contemporary system of regional orderwhether East Asian or the more expansive Asia-Pacific-are that it has been dominated by a comparatively new regional actor, and direct coercive power has been a prominent feature of its engagement at times. Although the United States may have initially been something of a reluctant imperialist (Mallaby 2002), it is important to remember that when it announced its arrival as a regional actor by compelling Japan to open up, it did so through naval power (LaFeber 1997). In the twentieth century American international leadership has been far more unambiguous and direct; a reality that was driven by the East Asia's position as one of the epicenters of the Cold War superpower struggle with the Soviet Union (Cronin 1996).

The transformation of the international order that underpinned American dominance in the middle of the twentieth century may have conferred a degree of 'structural' power and ascendancy on the United Stares (Strange 1994), but the way it was exercised was far from pre-determined or universal. On the contrary, the widely noted difference between America's multilateral institution-building efforts in Europe, and its bilateral hub-and-spokes relationships in East Asia, is striking and had long term consequences for the region (Beeson 2005; Hemmer and Katzenstein 2002). Not only did the US establish itself as the dominant power in the East Asia, albeit primarily as an 'off-shore balancer', but it also made the emergence of indigenous leadership much more difficult (Cha 2016): Japan was firmly established as a subordinate state, while China was still an unimportant economic backwater on 
the wrong side of the Iron Curtain. In such circumstances, the US provided a form of 'long distance leadership' for the non-communist states (Beeson 2008), a position it was prepared to defend via its direct participation in the wars in Korea and Vietnam.

The comparative point to emphasize, therefore, is that from the inception of America's hegemonic dominance of East Asia there was nothing remotely comparable to the development of the North Atlantic Treaty Organization (NATO), much less the sort of institutionalization that would ultimately culminate in the formation of the EU. 'East Asia' was simply a way of describing a geographical region that included China, Japan, the divided Korean peninsula, the less powerful states of Southeast Asia, and the anomalous island of Taiwan. In such circumstances the possibility that there might be any form of region-wide leadership or even collective action was null. Even when some of the Southeast Asian states formed the Association of Southeast Asian Nations (ASEAN), it was largely in response to the geopolitical maneuvering of extra-regional powers. Equally importantly, ASEAN as an institution was intentionally designed to have minimal influence over its members and little capacity for effective leadership of Southeast Asia, much less the wider East Asian region (Beeson 2009a).

In sum, therefore, the principal impact of American leadership in East Asia was to nullify the emergence of any indigenous regional rival. And that was precisely the intention, of course. Apologists for this course of action claim that American policy has contributed to regional stability, without which East Asia might have descended into chaos (Berger 2000; Feigenbaum 2011; Friedberg 2011). Whatever one thinks of such arguments which, it should be noted, emanate primarily from the US itself, there is little question that the net effect of American hegemony was to inhibit the rise of regional East Asian powers capable of providing leadership collectively or individually. Even in the more broadly conceived Asia-Pacific region, in which the US was itself ostensibly the leading player, an American aversion to constraining multilateral institutions meant the successive administrations evinced little enthusiasm for organizations such as the Asia Pacific Economic Cooperation (APEC) forum or the potentially important but underperforming ASEAN Regional Forum (ARF) (Beeson 2014).

The combination of an enduring pattern of American foreign policy that was predicated on discouraging indigenous regional leadership, a range of institutions that were consciously designed to have little leverage over their members, and unresolved historical animosities and rivalries that effectively thwarted the very possibility of regional cooperation much less collective leadership, have meant that East Asia and/or the Asia-Pacific have been largely incoherent and directionless. And yet the region-however it is defined-is in a state of flux. The rise of China and the possible decline — relatively, at least—of the US has generated a degree of uncertainty about America's traditional role an off-shore power (Mearsheimer and Walt 2016), and raised the prospect that China might once again reassume its regional leadership position. Before trying to assess how the dynamics of great power rivalry might play themselves out and what impact this might have on regional leadership, it is useful to put the evolving regional and world order in some sort of theoretical and comparative context. 


\section{The New World (Dis)Order}

Only a couple of decades ago some people were predicting that an era of unipolarity had arrived in which the United States had achieved a position of dominance that was unmatched since ancient Rome. The claim was that this power would not only endure for the foreseeable future, but it would bring about an era of stability. All that was required for unipolarity to endure, it was suggested, was

maintaining the expectation on the part of other states that any geopolitical challenge to the United States is futile. As long as that is the expectation, states will likely refrain from trying, and the system can be maintained at little extra cost (Wohlforth 1999: 40).

Even before the Iraq crisis undermined the foundations of American dominance, this argument looked implausible (Layne 1993). It would, however, require the events of September 11 and the disastrously ill-conceived response of George W Bush to demonstrate just how fragile and transient the 'unipolar moment' actually was (Mann 2004). Even if we accept that the Bush administration's policies unnecessarily undermined America's material power and ideational authority, the idea that the US would be able to maintain an unchallenged hegemonic dominance indefinitely looked like rather complacent wishful thinking on the part of American scholars in particular.

In retrospect it is possible to understand why so many appeared to be persuaded that American dominance the particular world order over which it presided and which it had done so much to create would endure. Not only did it seem as if ideological alternatives had disappeared along with the Soviet Union, but earlier claims about possible American demise during the 1980s had come to seem overblown and simply wrong (Brzezinski 1997). The renaissance of the American economy in the 1990s, the decline of Japan as competitive force, and the apparent absence of a credible geo-strategic rival led some to conclude that American primacy was assured-seemingly forever, according the likes of Wohlforth.

In one of the great ironies of recent world history, however, American unipolarity was not only short-lived, but the US was actually instrumental in bringing about its own downfall and encouraging the rise of competing powers. In much the same way that American hegemony and the creation of an open economic order had facilitated the economic renaissance of Japan, the People's Republic of China (PRC) was catapulted to the forefront of world economic development in large part as a consequence of Americans actions (Stubbs 2005). By imposing very demanding conditions on China when it tried to join the World Trade Organization (WTO), opposition to market-oriented reform in China was curbed and integration into the global capitalist economy turbo-charged economic development (Breslin 2007). The result was the inadvertent creation of genuine peer competitor and long-term threat to American dominance.

It was not simply the rise of China's material power that had undermined American dominance, however. The so-called 'global financial crisis' had a major impact on the relative standing of the US and China (Kirshner 2014). Two points are 
worth emphasising about the GFC as a consequence. First, it was no such thing. In reality the 'global' crisis only had a dramatic impact on the US and the European Union-at least initially. The major impact on the US in particular was not only material, however and this leads to a second point: the authority, standing and attractiveness of the so-called Anglo-American model of capitalism was dramatically undermined by the GFC. This loss of ideational influence was at least as important in changing the relative standing of the US and China as was any direct loss of material importance. Although the impact on the American economy was real and enormously damaging, the sense that the US's approach to economic management was deficient in comparison to other states had an enduring impact on its position. Indeed, not only was China relatively unaffected by the GFC thanks to a massive and very effective package of domestic stimulus measures (that also kept its neighbours afloat), but Chinese policymakers also saw the GFC as an opportunity to take advantage of America's comparatively diminished position (Overholt 2009).

Even if China's efforts to challenge America's strategic position and institutional ascendancy does not achieve the results some fear, they are emblematic of a new international order. The position of the US is widely seen as diminished, at least in relative terms if not absolutely. The international order that the US was instrumental in creating, and which allowed it to express a distinctive and highly effective form of institutional power, is at best under strain, at worst, beginning to unravel (Broome et al. 2015). Declining American power and influence were seen as being real possibilities even before the election of Donald Trump (Layne 2012). What is so potentially transformative about the Trump administration is that he and many of his advisors have little time for-or possibly understanding of - the benefits that flowed form an effective multilateral order. The transformation or diminution of American leadership opens up a political space that others could-individually or collectively_seek to fill (Browne 2017). It is one thing for an opportunity to present itself; it is quite another for someone to seize it, however.

\section{Are There Alternatives to American Leadership?}

Even critics of American foreign policy and its impact would have to concede that, if nothing else, American hegemony provided a degree of stability and predictability to the operation of what might be broadly described as the international system. This is not to ignore the often contentious and coercive aspects of America's geostrategic policies, or the sometimes self-serving nature of its geoeconomic policies, either. However, for all its possible flaws, inconsistencies and unevenness 'American hegemony' provided an enduring backdrop against which more evanescent issues played themselves out (Agnew 2005). The question now is whether-assuming the doubters and critics are correct and American power is in relative or absolute decline (Layne 2012), any other country or countries can fill the space the US has occupied for half a century or so. Before trying to decide whether the China or any other combination of states or institutions can lead, it is worth reminding ourselves what 'leadership' consists of and what would be required if some other power of powers were to take on the mantle. 
In one of the most influential analyses of leadership, Kindleberger (1973) argued that an absence of leadership had directly contributed to the Great Depression and the subsequent outbreak of World War 2. The principal claim here was that for the international system, especially its economic components, to function effectively, a leader needed to provide a number of essential 'collective goods'. Without an open international economic order, stable currencies and a market of last resort, states risked falling back into the sort of mutually destructive policies that had brought about the Great Depression. It was the failure of the US to provide leadership between the wars that had brought about precisely this result.

The reason that the US ought to have played this role, in Kindleberger's view, was that it had become the most important economic actor in the international system, and it was therefore incumbent upon it to play the sort of system stabilizing role that Britain had done before World War 1 fatally undermined its position and that of Europe more generally. The reason that the international economy got into so much trouble and ultimately led to a geopolitical cataclysm was that the US failed to assume the leadership role that Britain was no longer capable of fulfilling. On the contrary, an isolationist America between the wars actually exacerbated economic and political problems, rather than mitigating them. The key questions at the present moment, therefore, are firstly about whether the US any longer has the willingness or the capacity to play such a role in the future, and secondly, whether any other state or states could replace it should it fail to provide such leadership.

\subsection{Is There a Leadership Vacuum?}

If there is one thing on which most observers seem to agree, it is that Donald Trump's administration represents a major departure from previous American foreign policy positions (Erlanger 2017). Trump's supposedly 'transactional' approach to foreign policy, in which he seeks to make deals that privilege American interests above all else would seem to be the very antithesis of the sort of leadership that Kindleberger and others think is a prerequisite for a stable, rules-based international order. And in many ways it is, of course: the apparent contempt which many of Trump's advisors appear to have for multilateral institutions and the liberal principles that notionally underpin them mark a very different approach to, if not an abdication of leadership as it has traditionally been understood in the US (Sevastopulo 2017).

And yet we need to recognize that leadership, even the 'hegemonic' variety, need not be based on either multilateralism or on the enthusiastic consent of the subordinate powers. On the contrary, coercive forms of international leadership have arguably been more common than the consensual sort (Snidal 1985). Indeed, the construction of a complex, interlocking network of multilateral institutions in the period following the Second World War was a distinctive and novel feature of the international order the US did so much to create. It is worth noting that the Soviet Union's style of leadership was both less institutionalized and less consensual. While the US may also have intervened directly and coercively in the affairs of client states on occasion, on the whole its dominance was widely supported by its powerful allies in particular. Even 'critical' and/or Marxist scholars 
have long recognized that American hegemony was successful in large part because it provided benefits to many countries and consequently had either their enthusiastic support or grudging compliance (Cox 1987). The point to emphasize is that the 'transaction costs' involved in maintaining a US-centric international order were significantly reduced by an absence of significant opposition to American leadership.

What is unclear at this stage is firstly, whether the Trump administration will significantly undermine the existing array of multilateral institutions by failing to support them; secondly, how much this will matter even if they do; and thirdly whether another state or states could actually fill the leadership gap that is apparently being vacated by the US. None of these questions is easily answered, not least because the Trump administration's foreign policy agenda is apparently highly contested internally and consequently very difficult to predict (Donnan and Sevastopulo (2017). Nevertheless, it is possible to identify some important variables that will help to determine not just the impact of the Trump administration, but also the constraints and opportunities that may confront any state or grouping that seeks to replace it.

One of the most widely noted characteristics of the international organizations (IOs) that have become such an important and numerous feature of the contemporary international system is that once established, they have the capacity to take on a life of their own (Barnett and Finnemore 1999). Indeed, it is not just formal inter-governmental IOs that have become prominent and functionally necessary parts of the global economy in particular, but an array of private sector actors and institutions, without which even limited 'global governance' would be very difficult (Cutler et al. 1999). There are two points to emphasize to emphasize as a consequence. First, even if the Trump administration fails to support or appreciate the importance of this dense institutional architecture that exists outside of individual states, this does not mean that it will disappear. On the contrary, it may actually become more important as other states and non-government actors seek to preserve a functionally important institutional infrastructure.

The second point to emphasize in this context, therefore, is that any state or states seeking to supplant the American position will either have to work within the existing order or provide a credible alternative. Given that many of the regulatory regimes in specific issue areas such as finance, insurance, health and the environment are now frequently maintained by non-state actors (Braithwaite and Drahos 2000), this would be a major challenge and one that might be expected to induce a good deal of push-back from existing agencies. There is, in short, a degree of path dependency to the existing order that will make radical change unlikely, even if the Trump administration fails to support the status quo. And yet the apparent unwillingness of the Trump regime to continue providing to sorts of collective goods that are traditionally associated with successful leadership has led some observers to claim that East Asians have the capacity to develop a political presence that mirrors what many see as the inexorable shift in power for 'West' to 'East' (Mahbubani 2008). 


\section{Can Asia Lead?}

Somewhat surprisingly it is not the giants of the Asian region that are generally considered to have the capacity to provide leadership, but some of its relative minnows. Indeed, it is the relatively non-threatening nature of ASEAN's states that makes their possible leadership potentially attractive, according to some observers. Acharya (2011: 862-3), for example, suggests that

although Japan, China increasingly and India to a lesser extent all have the resources to lead, all still suffer from a deficit of regional legitimacy deriving from past histories (the Japanese wartime role, Chinese subversion and Indian diplomatic arrogance, dating back to the Bandung conference). Moreover, their mutual rivalry prevents the Asian powers from assuming regional leadership singly or collectively. Hence, regional leadership rests with a group of the region's weaker states.

ASEAN is 'in the driving seat' as far as regional leadership is concerned, the argument goes, because there is an absence of great power leadership or the sort of collective leadership that a concert of powers might provide (Stubbs 2014). In such circumstances, the great powers are happy to give ASEAN a greater role.

While there is clearly something in the idea that great power rivalries have stymied collective or individual great power leadership in East Asia-or even the Asia-Pacific, for that matter-it is much more debatable that 'lesser power leadership' follows as a consequence. On the contrary, ASEAN as an organization has been notoriously feeble when it comes to offering decisive direction to its own members, let alone the wider East Asian region (Beeson 2015). The one example of effective diplomatic leadership that is routinely trotted out in support of ASEAN's diplomatic capabilities is the resolution of the Cambodian crisis in the 1980s. But as has been pointed out, one reason that ASEAN played a seemingly effective role was that it suited the great powers' own interests for it to do so (Jones and Smith 2001).

Likewise, when the economic crisis of the late 1990s laid a number of the ASEAN economies low, ASEAN as an organization, much less an effective crisis manager was nowhere to be seen. In reality the US, in cooperation with key extra regional organizations such as the International Monetary Fund (IMF), did the heavy lifting in addressing the crisis and managing its aftermath. Even where there was a belated regional response, it was led_rather ineffectually_by Japan and then latterly China. In neither case did mechanisms of regional cooperation prove terribly effective or decisive, however. Indeed, even the much-ballyhooed inauguration of the Chiang Mai Initiative (CMI) of currency swap arrangements, which some observers took to be a landmark in effective regional cooperation, was not actually utilized in the GFC. To be fair, China's proactive response to the GFC meant that a currency crisis and/or economic downturn was largely averted, but this only serves to highlight the limited impact of a series of regional institutions and organizations that subscribed to the paralyzing logic of the 'ASEAN Way' of consensus, facesaving and compromise. 
Admirers of ASEAN's abilities and potential for leadership like to emphasize its supposed capacity for promoting particular forms of behavior and mediating, if not generating norms, that can influence the way more powerful states behave. This 'socialization' process, the argument goes, is a distinctive and important part of contemporary international relations in which less powerful states can paly a more prominent ideational role. In an era when inter-state conflict has declined and in which material power seems less efficacious, there would seem to be something in this. And yet, it is clear that there are limits to this process.

Faced with what is arguably the biggest security challenge of its 50-year existence, ASEAN has been unable to come up with a coherent, collective position on how to respond to China's increasingly assertive claims to much of the South China Sea. Equally importantly, China appears to have been entirely unaffected by ASEAN's norms or the actions of its individual neighbors, unless being entirely comfortable with ASEAN's undemanding diplomatic standards is considered to be evidence of socialization. In reality, China has skillfully divided the ASEAN grouping of the South China Sea issue by effectively buying the support of Cambodia and to a lesser extent Laos (Kynge et al. 2016). The consequence has been that it has been impossible to reach a consensus position on this more critical of issues.

Even if it is proving increasingly difficult for ASEAN to fulfill a leadership role, as far as China's recent actions might be construed as designed to fill this gap. At one level, it is plain that China is applying a form of coercive and/or instrumental foreign policy that is undoubtedly beginning to influence regional economic and strategic outcomes. Whether this constitutes leadership is a moot point. Ikenberry (1996: 388) suggests that international leadership should be thought of as:

the ability to project a set of political ideas or principles about the proper or effective ordering of politics. It suggests the ability to produce concreted or collaborative actions by several states or other actors. Leadership is the use of power to orchestrate the actions of a group toward a collective end.

China's actions in the South China Sea and its efforts to apply a divide and rule policy among ASEAN's members are clearly unlike the persuasive and cooperative approach Ikenberry has in mind. On the contrary, China has until recently had little 'soft power' or diplomatic leverage on which to draw to influence other states (Beeson and $\mathrm{Xu} 2015$ ); but this may be changing. Indeed, in what may prove to be an important indicator of the multidimensional nature of China's evolving foreign and strategic policies its policymakers have recently unveiled a number of ambitious 'grand strategic' initiatives that may offer both an alternative to the institutional order that the US did so much to create, as well as a blueprint for consolidating China's material importance to Asia as a whole (NDRC 2015).

\subsection{Can China Lead Asia?}

It is important to remember that the very idea of the PRC providing leadership for the East Asian region would have been considered as absurd by many observers until relatively recently. After all, only 30 years or so ago, China was regarded as an 
underdeveloped, largely agrarian backwater of no economic importance. What 'leadership' credentials China did have before the era of reform initiated by Deng Xiaoping were largely confined to the export of revolutionary and destabilizing ideology (van Ness 1970). At one level, then, 'China' clearly has undergone a profound reorientation in its foreign policy behavior and its officials plainly have undergone a process of socialization (Johnston 2008). At another level, however, the changes in China's foreign policy may be less dramatic than they seem. The pursuit of 'national interests' continues to be the dominant theme in China's foreign policy (Lampton 2008; Shambaugh 2013); it is the means of pursuing them that has undergone the greatest change.

One of the most important developments in recent China's recent foreign policy agenda, which will help determine whether it can lead, has been its increased centralization as part of series of reforms initiated under the leadership Xi Jinping. Until relatively recently, China's notoriously opaque foreign policy process was subject to numerous, often conflicting pressures and influences, that made it unpredictable and seemingly ad hoc (Jakobson and Knox 2010). The concentration of power under $\mathrm{Xi}$ as the 'core leader' is one response to this issue (Johnson and Kennedy 2015), and one of the consequences has been the articulation of an ambitious and integrated program that is designed to transform China's diplomacy and international standing, and to consolidate the Chinese economy's position at the center of regional development and production (Wang 2016).

The One Belt, One Road (OBOR) scheme and the associate Asia Infrastructure Investment Bank (AIIB) could, if successfully implemented, be the Asian equivalent of the Marshall Plan, with a similar sort of geopolitical and geoeconomic impact (Miller 2017). Simply put, the highly ambitious OBOR project will directly link China to markets in Europe via key regional states in Central, South and Southeast Asia. The AIIB will be instrumental in providing the finance for much of this project, providing an alternative institutional order to the one dominated by the US for so long, while simultaneously making many of it neighbors even more economically dependent on China in the process. Under such circumstances, there is simply no doubt that China's influence and material importance to much of the region will be significantly enhanced. The fact that key allies of the US such as the UK and Australia decided to join despite the Obama adminstration asking them not to is indicate of how much economic leverage China already has (Branigan 2015).

Nevertheless, it is one thing to have economic leverage and even the potential to create new institutions, it is quite another to have a vision for an alternative international order. As Shambaugh (2013: 153) points out, 'China is more confident and active in international organizations but still exhibits a "defensive" posture in many negotiations. It is a nation that knows what it is against but not necessarily what it is for'. Even the so-called 'Beijing consensus' and the 'Chinese model of development' remain under-defined, very difficult to replicate, and concepts that the Chinese government itself appears to be ambivalent about the reluctant to promote as part of an explicit foreign policy agenda (Breslin 2013; Ferchen 2013). Indeed, some observers fear that China is 'is so wedded to the status quo that China will forestall important reforms that are desperately needed' (Kennedy 2012: 11). 
Paradoxically enough, however, in the aftermath of the election of Donald Trump, China has emerged as an unexpected champion of 'globalization'. In part, this reflects a recognition on the part of China's leaders that the country has been one of the principal beneficiaries of an open international economic order. At the same time, however, Xi (2017) in particular clearly sees an opportunity for China to reposition itself as precisely the sort of 'responsible stakeholder' that some have long called for (Zoellick 2005). At a time when the Trump administration seems to be abandoning the traditional American role in favor of a more instrumental, nationalistic approach to trade and even security policy (Browne 2017; Hodge 2017), Chinese officials have been quick to seize the moment and the initiative.

There are, however, continuing constraints confronting China that raise real questions about its ability to offer a leadership at the regional, much less the global level. First, the extant international order will not be easily replaced, nor will America's role within it. The fact remains that the US is still the world's preeminent economic and military power, albeit one with diminished status and damaged authority. Second, China has shown little desire or capacity to articulate an alternative vision for the international system, thus far, and seems willing to work within existing institutional architecture and avoid the costs associated with leadership (Wang and French 2014). Third, leaders need followers, and at this stage-despite an apparently growing diplomatic influence in Southeast Asia-it has few allies and friends. Indeed, the fourth point to make is that China's continuing pursuit of its own nationalistic goals, especially its claims in the South China Sea dispute, look certain to make its future relations and role divisive and contentious.

\section{Concluding Remarks}

The most striking feature of the East Asian region since the Second World War is that indigenous leadership has been in short supply. Even before this, what leadership attempts there had been were abortive and imperialistic (Beeson 2009b), rather than the sort of consensually determined collective actions envisaged by admirers of either ASEAN or the supposedly benign form of long distance leadership offered by the US. The causes of this local vacuum are not difficult to discern: institutional limitations on the part of ASEAN and its offshoots, especially when combined with unresolved historical and contemporary regional tensions and rivalries, have meant that no state or intergovernmental organization has been able to provide effective leadership. Even more tellingly, however, America's postwar dominance of the region and the ultimately divisive hub and spoke strategic architecture have meant that challengers to it hegemonic position have been nullified (Cha 2016). Effective leadership form within Asia has been all but impossible.

It is this historical pattern of American dominance that makes the advent of the Trump administration so significant. It is far from clear that the new regime in Washington is committed to play the same sort of role that it has done as an offshore balancer, or give alliance the sort of guaranteed support that is thought by 
many observers to have contributed to relative stability in the region. Whatever one thinks about the claims made about the old order that the US underpinned and largely shaped, it is entirely possible that something different may be emerging: the rise of an increasingly assertive China and the more transactional, less principled approach of the Trump regime means that many of the taken for granted features of the Asia-Pacific and East Asian regions may be in doubt and up for renegotiation.

In this rather febrile and uncertain atmosphere it is foolhardy to make predictions but, as I have suggested, there are still major obstacles facing China-or anyone else, for that matter-if they hope to play a decisive leadership role in the region. Perhaps the best hope, both for more effective collection action and for the stability of the region is that some sort of accommodation can be reached in which both a rising China, the concerns of other less powerful regional states, as well as a possibly declining hegemon can be accommodated. Unlikely as it may seem to some observers, especially in the US, it may be a lot more attractive than the alternative. The history of East Asia is a sobering reminder of just what can happen when leadership is contested and coerced.

\section{References}

Acharya, A. 2011. Can Asia lead? Power ambitions and global governance in the twenty-first century. International Affairs 87 (4): 851-869.

Agnew, J. 2005. Hegemony: The New Shape of Global Power. Philadelphia: Temple University Press.

Barnett, M.N., and M. Finnemore. 1999. The politics, power, and pathologies of international organizations. International Organization 53 (4): 699-732.

Beeson, M. 2005. Rethinking regionalism: Europe and East Asia in comparative historical perspective. Journal of European Public Policy 12 (6): 969-985.

Beeson, M. 2008. The United States and East Asia: The decline of long-distance leadership? In China, Japan and Regional Leadership in East Asia, ed. C.M. Dent, 229-246. Cheltenham: Edward Elgar.

Beeson, M. 2009a. Institutions of the Asia-Pacific: ASEAN, APEC and Beyond. London: Routledge.

Beeson, M. 2009b. Geopolitics and the making of regions: The fall and rise of East Asia. Political Studies 57: 498-516.

Beeson, M. 2014. Regionalism and Globalization in East Asia: Politics, Security and Economic Development, 2nd ed. Basingstoke: Palgrave.

Beeson, M. 2015. Can ASEAN Cope with China? Journal of Current Southeast Asian Affairs 35 (1): $5-28$.

Beeson, M. 2016. Multilateralism in East Asia: Less than the sum of its parts? Global Summitry 2 (1): 54-70.

Beeson, M., and S. Xu. 2015. Leadership with Chinese characteristics: What role for soft power? In Global and Regional Leadership of BRICS Countries, eds. S. Kingah and C. Quiliconi, 169-188. London: Springer.

Berger, T. 2000. Set for stability? Prospects for conflict and cooperation in East Asia. Review of International Studies 26 (3): 405-428.

Braithwaite, J., and P. Drahos. 2000. Global Business Regulation. Cambridge: Cambridge University Press.

Branigan, T. 2015. Support for China-led development bank grows despite US opposition. The Guardian, 14 March.

Breslin, S. 2007. China and the Global Economy. Basingstoke: Palgrave.

Breslin, S. 2013. China and the South: Objectives, actors and interactions. Development and Change 44 (6): 1273-1294.

Broome, A., L. Clegg, and L. Rethel (eds.). 2015. Global Governance in Crisis. London: Routledge. 
Browne, A. 2017. A U.S.-China role switch: Who's the globalist now? Wall Street Journal, January 24.

Brzezinski, Z. 1997. The Grand Chess Board: American Primacy and Its Geostrategic Imperatives. New York: Basic Books.

Cha, V.D. 2016. Powerplay: The Origins of the American Alliance System. Princeton: Princeton University Press.

Cox, R.W. 1987. Production, Power, and World Order: Social Forces in the Making of History. New York: Columbia University Press.

Cronin, J.E. 1996. The World the Cold War Made: Order, Chaos, and the Return of History. London: Routledge.

Cutler, A.C., V. Haufler, and T. Porter. 1999. Private authority and international affairs. In Private Authority and International Affairs, eds. A.C. Cutler and et al, 3-28. New York: State University of New York.

Donnan, S., and D. Sevastopulo (2017) White House civil war breaks out over trade. Financial Times, March 11.

Emmott, B. 2008. Rivals: How the Power Struggle Between China, India and Japan Will Shape Our Next Decade. London: Allen Lane.

Erlanger, S. 2017. As Trump era arrives, a sense of uncertainty grips the world. New York Times, January 16.

Fairbank, J.K., E.O. Reischauer, and A.M. Craig. 1965. East Asia: The Modern Transformation. Boston: Houghton Mifflin.

Feigenbaum, E.A. 2011. Why America no longer gets Asia. The Washington Quarterly 34 (2): $25-43$.

Ferchen, M. 2013. Whose China model is it anyway? The contentious search for consensus. Review of International Political Economy 20 (2): 390-420.

Friedberg, A.L. 2011. A Contest for Supremacy: China, America, and the Struggle for Mastery in Asia. New York: W.W. Norton.

Hemmer, C., and P.J. Katzenstein. 2002. Why is there no NATO in Asia? Collective identity, regionalism, and the origins of multilateralism. International Organization 56 (3): 575-607.

Hobson, J.M., and J.C. Sharman. 2005. The enduring place of hierarchy in world politics: Tracing the social logics of hierarchy and political change. European Journal of International Relations 11 (1): 63-98.

Hodge, A. 2017. Donald Trump is bulldozing allies of Obama's China pivot. The Australian, January 14.

Ikenberry, G.J. 1996. The future of international leadership. Political Science Quarterly 111 (3): 385-402.

Jakobson, L., and D. Knox. 2010. New foreign policy actors in China. SIPRI Policy Paper 26 (September).

Johnson, C.K., and S. Kennedy. 2015. China's Un-Separation of Powers. Foreign Affairs, July 24.

Johnston, A.I. 2008. Social States: China in International Relations, 1980-2000. Princeton: Princeton University Press.

Jones, D.M., and M.L. Smith. 2001. The changing security agenda in Southeast Asia: Globalization, new terror, and the delusions of regionalism. Studies in Conflict and Terrorism 24: 271-288.

Kang, D.C. 2003. Getting Asia wrong: The need for new analytical frameworks. International Security 27 (4): 57-85.

Kennedy, S. 2012. China in global governance: What kind of status quo power? In The Growing Role of Chinese in Global Governance, eds. S. Kennedy and S. Cheng, 9-21. Bloomington: Research Centre for Chinese Politics and Business.

Kindleberger, C.P. 1973. The World in Depression 1929-1939. Berkeley: University of California Press. Kirshner, J. 2014. American Power after the Financial Crisis. Ithaca: Cornell University Press.

Kynge, J., L. Haddou, and M. Peel. 2016. How China bought its way into Cambodia. Financial Times, September 8 .

LaFeber, W. 1997. The Clash: US-Japanese Relations Throughout History. New York: WW Norton.

Lampton, D.M. 2008. The Three Faces of Chinese Power: Might, Money, and Minds. Berkeley: University of California Press.

Layne, C. 1993. The unipolar illusion: Why new great powers will rise. International Security 17 (4): 5-51.

Layne, C. 2012. This time it's real: The end of unipolarity and the Pax Americana. International Studies Quarterly 56 (1): 203-213.

Mahbubani, K. 2008. The New Asian Hemisphere: The Irresistible Shift of Global Power to the East. New York: Public Affairs. 
Mallaby, S. 2002. The reluctant imperialist: Terrorism, failed states, and the case for American empire. Foreign Affairs 81 (2): 2-7.

Mann, M. 2004. The first failed empire of the 21st century. Review of International Studies 30: 609-630. Mearsheimer, J.J., and S.M. Walt. 2016. The case for offshore balancing. Foreign Affairs 95: 70-84.

NDRC (National Development and Reform Commission. 2015. Vision and Actions on Jointly Building Silk Road Economic Belt and 21st-Century Maritime Silk Road. Beijing: Ministry of Foreign Affairs, and Ministry of Commerce of the People's Republic of China. <http://en.ndrc.gov.cn/ newsrelease/201503/t20150330_669367.html>.

Overholt, W.H. 2009. China in the global financial crisis: Rising influence, rising challenges. The Washington Quarterly 33 (1): 21-34.

Rozman, G. 1991. The East Asian region: Confucian Heritage and Its Modern Adaptation. Princeton: Princeton University Press.

Sevastopulo, D. 2017. Donald Trump's foreign policy spins on an axis of upheaval, 9. Times Feb: Financial.

Shambaugh, D. 2013. China Goes Global: The Partial Power. Oxford: Oxford University Press.

Snidal, D. 1985. The limits of hegemonic stability theory. International Organization 39 (4): 579-614.

Strange, S. 1994. States and Markets, 2nd ed. London: Pinter Publishers.

Stubbs, R. 2005. Rethinking Asia's Economic Miracle. Basingstoke: Palgrave.

Stubbs, R. 2014. ASEAN's leadership in East Asian region-building: strength in weakness. The Pacific Review 27 (4): 523-541.

Van Ness, P. 1970. Revolution and Chinese Foreign Policy: Peking's Support for Wars of National Liberation. Berkley: University of California Press.

Wang, H., and E. French. 2014. China in global economic governance. Asian Economic Policy Review 9 (2): 254-271.

Wang, Y. 2016. Offensive for defensive: The Belt and Road Initiative and China's new grand strategy. The Pacific Review 29 (3): 455-463.

White, H. 2012. The China Choice: Why America Should Share Power. Melbourne: Black Inc.

Wohlforth, W.C. 1999. The stability of a unipolar world. International Security 24 (1): 5-41.

Xi, J. 2017. President Xi's speech to Davos. World Economic Forum, 17 January.

Zhang, Y., and B. Buzan. 2012. The Tributary System as international society in theory and practice. The Chinese Journal of International Politics 5 (1): 3-36.

Zoellick, R.B. 2005. Whither China: From Membership to Responsibility? New York. http://2001-2009. state.gov/s/d/former/zoellick/rem/53682.htm.

Mark Beeson is Professor of International Politics at the University of Western Australia. Before joining UWA, he taught at Murdoch, Griffith, Queensland, York (UK) and Birmingham, where he was also head of department. He is the founding editor of Critical Studies of the Asia Pacific. 